\title{
PENDEKATAN COMMUNICATIVE LANGUAGE TEACHING DALAM VIDEO PROJECT YOUTUBE UNTUK MENINGKATKAN MOTIVASI BELAJAR SISWA
}

\author{
Titin Kustini \\ Universitas Majalengka \\ t.kustini@gmail.com
}

\begin{abstract}
Learning motivation is closely correlated with increasing learning achievement in English. Because of the importance of motivation for improving student learning it is necessary to look for ways that are felt appropriate for students. The activeness of students in using English can be improved by using the Communicative Language Teaching (CLT) approach. The aim of CLT is teaching communicative language competence. In addition, the progress of science, especially the internet and information technology, in this case social media, including Youtube, which has become a part of the daily life of the younger generation, can be an alternative way to increase student motivation in learning English. The assignment to make a video project which is then uploaded to Youtube is expected to increase students 'motivation to learn English and at the same time stimulate students' creativity so that they are not only viewers but can benefit from Youtube. The first expected benefit is increased student motivation to learn English when their videos on Youtube are watched by many viewers. The second benefit is growing students' entrepreneurial spirit by making Youtube as an alternative that can bring economic benefits. The method used in this research is qualitative. Qualitative research is an attempt to obtain data in the form of a description of the things observed. The results showed that the assignment of the video project could increase students' motivation to improve learning achievement in English but was unable to be an alternative way to bring economic benefits because they encountered many obstacles in finding a significant number of viewers related to the condition of the majority of students who came from the middle economic circle down.
\end{abstract}

Keywords: Video Project, Communicative Language Teaching, Youtube, Motivation to learn

\section{ABSTRAK}

Motivasi belajar terkorelasi erat dengan peningkatan prestasi belajar bahasa Inggris. Karena pentingnya motivasi bagi peningkatan belajar siswa maka perlu terus dicari cara yang dirasakan tepat bagi siswa. Keaktifan siswa dalam menggunakan bahasa Inggris dapat ditingkatkan dengan menggunakan pendekatan Communicative Language Teaching (CLT). Tujuan dari CLT adalah pengajaran kompetensi berbahasa komunikatif. Di samping itu kemajuan ilmu pengetahuan khususnya internet dan teknologi informasi dalam hal ini media sosial termasuk Youtube yang telah menjadi bagian keseharian generasi muda sekarang ini, bisa menjadi alternatif cara meningkatkan motivasi siswa dalam belajar bahasa Inggris. Penugasan membuat video project yang kemudian diupload ke Youtube diharapkan bisa meningkatkan motivasi siswa belajar bahasa Inggris dan sekaligus merangsang kreatifitas siswa agar tidak hanya menjadi penonton tetapi bisa memetik manfaat dari adanya Youtube. Manfaat pertama yang diharapkan adalah meningkatnya motivasi siswa untuk mempelajari bahasa Inggris ketika video mereka di Youtube ditonton oleh banyak viewers. Manfaat kedua adalah menumbuhkan jiwa wirausaha siswa dengan menjadikan Youtube sebagai salah satu alternatif yang bisa mendatangkan keuntungan ekonomis. Metode yang digunakan dalam peneliti ini adalah kualitatif. Penelitian kualitatif merupakan upaya untuk memperoleh data berupa deskripsi tentang hal-hal yang diamati. Hasil penelitian menunjukkan bahwa penugasan video project dapat meningkatkan motivasi belajar siswa sehingga meningkatkan prestasi belajar bahasa Inggris namun tidak mampu menjadi salah satu alternatif cara mendatangkan keuntungan ekonomis karena mereka menemui banyak hambatan dalam mencari jumlah viewers yang signifikan terkait kondisi mayoritas siswa yang berasal dari kalangan ekonomi menengah ke bawah.

Kata Kunci: Berisi dua sampai lima kata/frasa dengan tanda baca titik koma pemisah 


\section{Pendahuluan}

Salah satu permasalahan yang dihadapi siswa dalam belajar bahasa Inggris adalah bagaimana menemukan ide dan kemudian mengkomunikasikannya dengan menggunakan bahasa Inggris. Pencarian ide merupakan sebuah proses explorasi yang berujung pada sebuah pemahaman yang didasarkan pada pengalaman empirik (Lewis, 1986 dalam Harmer 2002). Setiap pengalaman yang dilakukan melalui proses inquiry yang didasarkan pada rasa ingin tahu akan lebih bermakna daripada hal-hal yang diajarkan secara terpaksa.

Kompetensi berbicara dalam bahasa asing adalah suatu keterampilan yang dicapai melalui pengalaman. Mengucapkan kata kata, menirukan intonasi penutur asli adalah sebagian pengalaman yang dilakukan di kelas dengan bimbingan seorang guru dengan bantuan kaset, cd ataupun perangkat teknologi lain (Brown, 2001). Harapannya adalah bahwa setiap siswa dapat mengucapkan dan memaknai bahasa Inggris dengan baik.

Salah satu upaya pembelajaran dengan pendekatan inquiry yang mencakup penemuan ide, mengkomunikasikan ide tersebut ke dalam bentuk tulisan, pengalaman belajar bersama dalam satu kelompok diharapkan dapat menjadi pembelajaran bersama (kolaboratif) yang lebih memberikan makna. Prinsip pembelajaran Bahasa Inggris yang bermakna sangat berkaitan erat dengan Communicative Language Teaching (CLT). Kebermaknaan berbahasa disini diukur dengan kompetensi seseorang dalam mengkomunikasikan gagasan ide atau pendapatnya yang dapat diterima dengan baik oleh orang lain (Richards, 1998; 2001). Untuk mendorong serta memotivasi siswa inilah maka dibuatlah penugasan video project yang kemudian diupload ke Youtube. Selain meningkatkan motivasi siswa dalam belajar bahasa Inggris juga untuk melatih kreatifitas siswa dalam memecahkan masalah, misalnya mencari alternatif pemasukan lain bagi uang kas kelasnya, tak hanya mengandalkan iuran semata tetapi dari royalti Youtube.

Keaktifan siswa dalam menggunakan bahasa Inggris dapat ditingkatkan dengan menggunakan pendekatan Communicative Language Teaching (CLT). Richards (2008) menyebutkan bahwa tujuan dari CLT adalah pengajaran kompetensi berbahasa komunikatif. Menurutnya, seseorang yang menguasai aturan-aturan pembentukan kalimat dalam suatu bahasa belum tentu belum mampu menggunakannya dalam komunikasi yang bermakna, maka inilah yang kemudian menggagas istilah communicative competence (Richards, 2008:4).

Richards menjelaskan bahwa kompetensi komunikasi antara lain: 1) mengetahui bagaimana menggunakan bahasa untuk berbagai maksud dan fungsi, 2) mengetahui bagaimana memvariasikan, 3) penggunaan bahasa kita sesuai dengan seting dan partisipannya, 4) mengetahui bagaimana memproduksi dan memahami berbagai jenis teks, 5) mengetahui bagaimana mempertahankan komunikasi walaupun memiliki batasan dalam pengetahuan berbahasa.

Selanjutnya CLT juga untuk dapat memahami kompetensi komunikatif ini, Richards menuntut siswa harus dilibatkan ke dalam praktek penggunaan bahasa secara langsung. Dia menyebutkan paling tidak siswa harus mengenal tiga jenis praktik dalam berkomunikasi, yaitu praktik mechanical, meaningful, dan communicative. Pembelajaran dengan menggunakan ketiga jenis praktik tersebut, yaitu: 1) Mechanical practice mengacu pada aktivitas praktik yang terkontrol, dimana siswa dapat berhasil melakukannya tanpa perlu memahami bahasa yang 
mereka gunakan. 2) Meaningful practice mengacu pada aktifitas dimana kontrol bahasa diperlukan tapi yang diperlukan adalah siswa mampu membuat pilihan yang bermakna saat mereka, 3) Communicative practice mengacu pada kegiatan-kegiatan dimana praktik dalam menggunakan bahasa dalam konteks komunikasi yang riil/ nyata menjadi (Richards, 2008: 16)

Merujuk pada ke sepuluh paradigma inti pembelajaran diatas Jacobs dan Farrell (dalam Richards 2008) menyarankan bahwa kondisi tersebut akan mendorong pada delapan buah perubahan dalam cara pengajaran sebuah bahasa. Perubahan- perubahan tersebut, yakni: 1) Learner autonomy (otonomi siswa) dalam menentukan arah pembelajaran, 2) The social nature of learning (kondisi alamiah dalam pembelajaran) dimana pembelajaran tidak lagi dilakukan secara individual tapi lebih mengarah pada proses kolaborasi sosial dimana satu individu berintaraksi dengan individul, 3) Curricular integration (integrasi kurikulum) dimana bahasa Inggris tidak lagi dipandang sebagai mata pelajaran yang berdiri sendiri namun lebih pada bagaimana bahasa tersebut juga terkait dengan mata pelajaran lainnya. Hal ini terkait juga dengan keterampilan siswa dalam mengolah dan mencerna berbagai macam teks yang ada dalam wacana mata pelajaran tersebut yang digunakan secara lintas kurikulum, 4) Focus on meaning (fokus terhadap kebermaknaan) dimana kebermaknaan dipandang sebagai dorongan utama dalam sebuah pembelajaran. Hal ini erat kaitannya dengan pendekatan Content-Based Teaching (CBT) yang mencari cara- cara yang efektif dalam menghubungkan makna dengan situasi tertentu dalam berbahasa melalui kegiatan-kegiatan yang diarahkan bagi pembentukan kebermaknaan itu sendiri, 5) Diversity (keragaman) yaitu adanya keragaman dan perbedaan potensi siswa sebagai individu yang memiliki keunikannya masing- masing dalam menjalani pembelajaran bahasa. Dengan demikian pembelajaran tidak dilakukan secara monoton dan pukul rata untuk setiap siswa dikelas, tapi harus lebih menekankan bagaimana siswa dapat menerapkan strateginya masing-masing dalam sebuah pembelajaran, 6) Thinking skills (kemampuan berpikir) dimana keterampilan berbahasa harus berfungsi untuk bisa meningkatkan kemampuan dalam berpikir, yang juga dikenal dengan cara berpikir kritis dan cara berpikir kreatif. Hal ini dimaknai sebagai kemampuan siswa untuk dapat mengaplikasikan keterampilan berbahasa tidak hanya dalam situasi kelas/ sekolah saja namun lebih jauh dapat mengaitkannya dalam kegiatan-kegiatan di luar kelas, yaitu dalam situasi nyata di masyarakat, 7) Alternative assessment (penilaian alternatif) yaitu format penilaian yang tidak hanya mengandalkan pada sistem penilaian yang didasarkan pada soal pilihan ganda saja namun lebih pada penilaian dalam berbagai bentuk lainnya seperti observasi, porto folio, interview dan membuat catatan harian (jurnal). Hal ini akan memberikan gambaran terhadap kemampuan siswa sebenarnya dalam menggunakan bahasa Inggris sebagai bahasa asing, 8) Teachers as co-learners (guru sebagai mitra belajar) dalam hal ini guru yang berperan sebagai fasilitator secara berkesinambungan dapat menjadi mitra belajar bagi seluruh siswa yang ada dibawah tanggungjawabnya dan selalu mencoba berbagai metoda alternatif yang berbeda dalam melaksanakan pembelajaran bahasa di dalam kelas (Jacob dan Ferell dalam Richards, 2008.

1. Motivasi Belajar

Motivasi adalah serangkaian usaha untuk memperoleh kondisi yang positif yang ditandai dengan adanya keinginan untuk melakukan sesuatu, di mana jika ia menghadapi 
situasi yang membuatnya enggan, ia akan bisa mengenyahkan perasaan itu. Dengan demikian, motivasi itu tumbuh dari dalam diri seseorang namun bisa distimulasi dengan faktor luar. Motivasi merupakan keadaan di mana anda membuat keputusan tentang (a) tujuan yang akan dicapai, (b) usaha anda untuk mencapai tujuan tersebut (Brown, 2001:72). Prinsip dari motivasi belajar adalah dorongan yang tergambar dalam berbagai kegiatan belajar, yang terutama terkait erat dengan kesadaran akan pentingnya belajar, bukan hanya takut terhadap hukuman. Fungsi motivasi belajar adalah tindakan mengarahkan dan melakukan (Syaiful Bahri Djamarah, 2008: 5357). Menurut Wasty Soemanto, guru semestinya menyadari dengan baik pentingnya motivasi selama mendidik siswa. Bermacam-macam teknik, seperti pemberian nilai yang bagus, reward, pujian dan lain- lain bisa digunakan untuk menumbuhkan keberanian siswa.

Seperti yang dikutip oleg Gage dan Berliner (979), menyarankan sejumlah cara untuk meningkatkan motivasi siswa tanpa harus mengubah kelas secara besar-besaran, yakni melalui bahasa verbal, memberikan tes dan penilaian dengan bijaksana, merangsang keingintahuan dan keinginan bereksplorasi, mengerjakan sesuatu yang luar biasa, menstimulasi hasrat anak, bermodalkan apersepsi terhadap siswa, menerapkan konsep atau prinsip-prinsip dalam konteks yang unik dan tidak biasa, meminta siswa untuk menggunakan istilah- istilah yang sudah dipelajari sebelumnya, menggunakan stimulasi dan game, meminimalisasi sistem-sistem yang berlawanan dengan tumbuhnya motivasi, meminimalisir konsekuensi yang tidak menyenangkan dengan melibatkan siswa dalam pembelajaran. Berdasarkan penjelasan di atas, maka untuk meningkatkan motivasi belajar siswa dalam bahasa Inggris digunakan video project yang selanjutnya diupload ke Youtube.

\section{Penugasan Video Project yang diupload ke Youtube}

Proses pembelajaran yang dilakukan melalui kegiatan ini menggunakan model inquiry yang terbagi menjadi tiga bagian: penulisan skenario (script writing), pembuatan gambar alur cerita (story board) dan penulisan sinopsis (video review).

Pada tahap awal, pembelajaran berfokus pada kemampuan menulis skenario dalam bahasa Indonesia yang selanjutnya diterjemahkan ke dalam bahasa Inggris. Pada penulisan skenario ini setiap kelompok siswa mencari gagasan atau ide untuk menulis konsep dialog yang menerangkan tentang tema-tema materi yang diajarkan di kelas XI seperti teks prosedur, dll. Peran guru adalah melihat konstruksi tata bahasa (English grammar) yang digunakan siswa dalam penulisan naskah tersebut. Tindakan koreksi dilakukan melalui diskusi kelompok untuk memperbaiki kesalahan baik dalam alur cerita maupun dalam penulisan bahasa Inggrisnya.

Pada tahap kedua dan ketiga, siswa dapat memilih untuk melakukan salah satu dari dua kegiatan yaitu; membuat gambar alur cerita atau story board atau membuat movie review atau sinopsis dari video yang dibuat. Namun ada juga kelompok yang berusaha untuk membuat kedua kegiatan tersebut.

Proses pembelajaran dalam memahami tema yaitu dengan mengidentifikasi informasi mengenai tema yang bisa dipilih dari materi-materi yang diajarkan di kelas XI. Selanjutnya, proses pembelajaran yang dilakukan selain di kelas, juga ditambah dengan bimbingan dari guru baik tentang muatan materi maupun progress shooting video. Setelah pembuatan video selesai, siswa menguploadnya ke Youtube. Youtube sendiri adalah sebuah situs web berbagi video yang 
dibuat oleh tiga mantan karyawan PayPal pada Februari 2005. Situs ini memungkinkan pengguna mengunggah, menonton, dan berbagi video. Perusahaan ini berkantor pusat di San Bruno, California, dan memakai teknologi Adobe Flash Video dan H00TML5 untuk menampilkan berbagai macam konten video buatan pengguna, termasuk klip film, klip TV, dan video musik. Selain itu ada pula konten amatir seperti blog video, video orisinal pendek, dan video pendidikan.

Jumlah netizen Indonesia yang menonton YouTube hampir menyaingi jumlah netizen yang menonton televisi. Hal ini terungkap dari Survei Google dan Kantar TNS pada Januari 2018. Menurut survei itu, YouTube ditonton oleh 53 persen pengguna internet di Indonesia. Sementara 57 persen netizen juga menonton televisi. Hal ini berbeda dengan radio yang hanya didengarkan 13 persen pengguna internet. Sekarang ini jumlah penonton Youtube mencapai 1,8 miliar orang per bulan. Siswa sekolah menengah merupakan rata-rata penonton Youtube. Dengan memanfaatkan fenomena ini maka video project yang sudah dibuat diharuskan diupload ke Youtube untuk lebih meningkatkan motivasi mereka dalam belajar bahasa Inggris sekaligus merangsang jiwa wirausaha siswa agar mereka tak hanya menjadi penonton semata tetapi mampu memanfaatkan keuntungan dari Youtube sebagai salah satu alternatif yang bisa mendatangkan keuntungan finansial minimal sebagai sumber lain untuk uang kas.

Sebanyak 5 judul video hasil karya siswa diupload ke akun Youtube kelas. Selanjutnya siswa menshare alamat Youtube ke guru untuk kemudian dilakukan penilaian. Untuk menjaring viewers sebanyak-banyaknya, setiap siswa wajib mengajak 10 orang anggota keluarga atau temannya untuk menonton video tersebut, mengklik like dan menshare video tersebut ke teman atau saudaranya yang lain sehingga dengan pesan berantai tersebut diharapkan jumlah viewers yang signifikan.

\section{Metode Penelitian}

Metode yang digunakan dalam penelitian ini adalah metode kualitatif. Penelitian kualitatif merupakan upaya untuk memperoleh data berupa deskripsi tentang hal-hal yang diamati. Menurut Bogdan dan Taylor (dalam Moleong, 2001:3) bahwa metode kualitatif adalah prosedur penelitian yang menghasilkan data deskriptif kata-kata tertulis atau lisan dari orang-orang dn perilaku yang dapat diamati. Penelitian kualitatif memiliki ciri tertentu yang berbeda dengan jenis penelitian kuantitatif. Menurut Bogdan dan Biklen (dalam Moleong, 2001: 4-8) bahwa ciri penelitian kualitatif adalah (1) berlatar ilmiah, artinya data yang dperoleh secara langsung; (2) bersifat deskriptif, artinya datayang diperoleh berupa kata-kata atau gambar; (3) lebih mengutamakan proses daripada hasil, bagian-bagian yang diteliti lebih jelas bila diamati dalam proses; (4) analisis data bersifat induktif.

\section{Hasil dan Pembahasan}

Setelah kegiatan penugasan video project yang diupload ke Youtube ini dilaksanakan, siswa dapat mencapai tujuan pembelajaran, yakni dari sisi pengetahuan sekaligus keterampilan. Selain itu juga mampu menumbuhkan jiwa wira usaha pada siswa sebagai bentuk pengembangan diri. Dari 
sisi pengetahuan, siswa lebih mudah memahami materi-materi yang diajarkan di kelas XI. Dan dari sisi keterampilan, siswa menjadi lebih aktif, percaya diri dalam berkomunikasi dengan menggunakan bahasa Inggris, kerjasama yang bagus dalam kelompok dan lebih meningkat motivasinya dalam belajar bahasa Inggris. Dari sisi pengembangan diri, tumbuhnya jiwa wirausaha ternyata belum berhasil menjadikan Youtube sebagai salah satu alternatif yang bisa mendatangkan keuntungan ekonomis, dalam hal ini sebagai sumber pemasukan uang kas karena terkendala faktor ekonomi di mana latar belakang ekonomi siswa merupakan kalangan menengah ke bawah sehingga kemampuan siswa untuk mempromosikan video mereka juga terbatas.

Video-video hasil karya mereka bisa dilihat di akun kelas XI TKJ 2 dengan alamat www.youtube.com/watch?v=B370si718dk.

\section{Simpulan}

Penugasan video project yang diupload ke youtube dapat meningkatkan motivasi belajar bahasa Inggris siswa kelas XI TKJ 2 SMKN 1 Kadipaten tahun pelajaran 2017-2018. Aktivitas siswa dalam proses interaksi tersebut ditandai dengan adanya partisipasi aktif dari seluruh siswa dalam tiap kelompok dalam pembuatan video dan meguploadnya di akun Youtube kelas. Selama dan setelah pembuatan video project tersebut terlihat motivasi mereka berkembang dengan baik dan menumbuhkan minat lebih untuk belajar bahasa Inggris.

Penugasan video project tersebut dapat meningkatkan siswa dalam speaking dan kerjasama kelompok serta memudahkan siswa dalam memahami materi kelas XI seperti misalnya teks prosedur, factual

\section{Daftar Pustaka}

Arikunto, Suharsimi. (2001). Prosedur Penelitian Suatu Pendekatan Praktek. Jakarta. Bina Aksara.

Brown, Douglas H., (2001). Teaching by Principles; An Interactive Approach to Language Pedagogy, Second Edition. Longman Inc.

Djamarah, Syaiful Bahri. (2008). Psikologi Belajar, Jakarta, PT. Rineka Cipta.

Gilbert, D. (2002). Multimedia Technology, Queensland: University of Queensland.

Harmer, Jeremy. (2002). The Practice of English Language Teaching. Pearson Education Limited.

Jasmadi,. (2007). Cara Mudah Mengolah Film Keluarga dengan Windows Movie Maker 2.1. Penerbit Andi, Yogyakarta.

Moleong, Kexy J. (2001). Metodologi Penelitian Kualitatif. Bandung. Remaja Rosdakarya. 
Richards, Jack C. (2008). Communicative Language Teaching Today. http \\: www. Jack C.Richards. co. id

Richards, Jack C and Theodore Rodgers .(2001). Approaches and Methods in Language Teaching. Second Edition. New York: Cambridge University Press.

Richards, Jack C and Charles Sandy. (1998). Passages. New York: Cambridge University Press.

Sitorus, Bergman. (1987). Membina Hasrat Belajar di Sekolah. Bandung. Remaja Rosdakarya.

Winke. (1989). Psikologi Pengajaran. Jakarta. Gramedia.

Wikipedia. Sejarah Youtube. Diakses pada 20 April 2019. 